\title{
A IRONIA COMO UM CONCEITO SEMIOLÓGICO
}

\author{
Arthur Bartholo ${ }^{1}$
}

\begin{abstract}
Resumo: O presente artigo traz uma abordagem do conceito de ironia sob o ponto de vista da semiologia, de maneira a tornar claros os fundamentos da relação dialética que a ironia estabelece com o simbólico, bem como delinear as condições dela ser utilizada como um instrumento de análise conceitual e semiótica. O texto procura trazer uma análise filosófica do conceito de ironia com referências a vários autores que a trouxeram enquanto uma tópica pertinente, e cujas obras, ainda que apenas indiretamente ligadas à ironia, possuem injunções particulares que permitem constituir um vínculo dialético com ela. Nesse sentido, a ironia aparece em sua ambiguidade fundamental, a saber, a de funcionar ao mesmo tempo enquanto uma figura estrutural da retórica e enquanto uma determinação em que o discurso ultrapassa dialeticamente a si próprio e abre espaço para o poético. Portanto, não se trata somente de uma elucidar a aplicabilidade da ironia enquanto um conceito a ser utilizado instrumentalmente, mas trata-se sobretudo de elaborar um ponto de vista irônico que condiciona esteticamente o ponto de vista semiológico.
\end{abstract}

Palavras-chave: ironia, semiótica, semiologia, símbolo, poético.

Abstract: The present article brings an approach of the concept of irony under the semiological point of view, intending to make the principles of the dialectical relation that irony establishes with the symbolical clear, as well as to describe the conditions for her being used as a conceptual and semiotical analysis instrument. The text seeks to bring a philosophical analysis of the concept of irony with references to many authors which have brought it along as a pertinent topica, and whose work, even if just indirectly connected with irony, still have particular injunctions that allow to constitute a dialectical link with it. In this sense, irony appears in its fundamental ambiguity: it functions at once as a rhetoric structural figure, and at the same time as a determination where the discourse goes dialectically beyond itself and open the borders for the poetic. Therefore, it is not just about elucidating an applicability of irony as an instrumentally oriented concept, inasmuch as elaborating an ironic point of view that aesthetically conditions the semiological point of view.

Keywords: irony, semiotics, semiology, symbol, poetical.

${ }^{1}$ Mestrando Faculdade de Arquitetura e Urbanismo - FAU Universidade de Brasília - UnB 


\section{A Ironia como um Conceito Semiológico}

O ponto de partida para uma análise da ironia enquanto conceito semiológico deve estabelecer-se numa equiparação entre o objeto próprio da semiótica, a saber, o símbolo ou a forma simbólica em geral, e a forma intencional da ironia, dado que esta não possui objeto em específico nem pode ser propriamente tipificada como um conceito da objetividade. Desde o início já aparecenos uma dificuldade: a semiologia, que dificilmente pode se qualificar categoricamente como um método interpretativo dentro da estética, possui no entanto um escopo de atuação bem definido e ela própria se constitui enquanto conceito a partir dele. O caso da ironia é outro; tem-se não só uma ausência de campo definido de aplicação ou atuação, como também uma indeterminação no que diz respeito a critérios através do qual estes pudessem ser concebidos. Ocorre que a ironia, mais do que uma figura de linguagem ou um mero tropos da retórica, permite um registro no qual ela se põe a si mesma enquanto algo que se aproxima de maneira constitutiva mais do movimento conceitual do que do próprio conceito enquanto articulação sistemática. Nesse sentido, ela não pode ter um lugar pré-definido num sistema qualquer de articulação sígnica, o que significa que uma concepção semiótica da ironia deve abandonar a pretensão de uma análise pura e objetiva para que o sujeito entre em jogo enquanto parte componente e determinante da própria análise. A elaboração de um conceito semiótico de ironia é determinado por um envolvimento dela própria no processo.

Mesmo enquanto figura de linguagem, a ironia parece sempre se conjugar mais à forma do que ao conteúdo do fenômeno em questão. Seu indício se dá na verdade na possibilidade de distanciamento do olhar do conteúdo em direção à forma, para que por meio desta ele seja redirecionado ao conteúdo que aparece de maneira agora diversa. Esse movimento, no entanto, precisa de uma mediação que não pode ser para o objeto nada senão o próprio observador; e dessa maneira a sua forma propriamente dita é a da subjetividade. A ironia trabalha com o mal-entendido, com a dubiedade e até mesmo com o exagero, mas sua marca característica é que ela se constitui no próprio distanciamento - estranhamento ${ }^{2}$; é portanto uma categoria essencialmente dialética. Ela só aparece enquanto tal nessa diferença, nessa inadequação; e seus traços são melhor definidos quanto maior a disparidade. Desse modo, no que diz respeito à forma simbólica do fenômeno, a sua diferença para com a ironia é que esta mostra tentando esconder, enquanto aquela esconde tentando mostrar. Compete portanto investigar em que sentido a ironia enquanto um conceito aplicado à semiologia permite um entrever mais rico dessa relação.

Vale a pena percorrer, do ponto de vista filosófico, como a definição do conceito de ironia se constitui em função da subjetividade. Essa temática foi explorada a fundo por Kierkegaard em seu

2 No sentido hegeliano da Entfremdung; pelo fato deste constituir um momento crucial na relação da dialética, a ironia pode ser analisada como um movimento que subjaz (sub-jectum) a todo movimento dialético.

REVISTA DE ESTÉTICA E SEMIOTICA, BRASÍLIA, V. 1, N. 2 P. 50-62, JUL./DEZ. 2011 
ARTHUR BARTHOLO

livro $O$ Conceito de Ironia, em que ele a relata como um conceito que se constitui primeiramente pelo seu fenômeno histórico, e em seguida pela elaboração histórica desse mesmo fenômeno a partir do ponto de vista conceitual. A primeira parte do livro se refere exclusivamente à aparição do fenômeno pelo qual a ironia se corporifica, e este é Sócrates: por meio deste " o conceito de ironia fez sua entrada no mundo" (KIERKEGAARD, 2005, p.23); enquanto na segunda parte desenvolve o conceito de ironia a partir dos românticos alemães até Hegel. De fato, para Kierkegaard a estreiteza da ligação da ironia com o movimento romântico é tão patente que ele se permite mesmo substituir um termo pelo outro ${ }^{3}$, mas sem perder de vistas a herança de Sócrates da ironia como ponto de vista. A definição desta enquanto fenômeno histórico é dada em função dos traços da sua personalidade, que aparecem nas aporias dos diálogos platônicos, no método socrático de interlocução, no dáimon socrático, no uso constante de alegorias, entre outros, a partir das quais Kierkegaard define a ironia socrática como o infinita e absoluta negatividade, no sentido de que Sócrates seria aquele personagem que, precisamente pelo fato de no seu perguntar não estar contida nenhuma resposta nem este ser capaz muitas vezes de fornecê-la, se deteria, em termos dialéticos, no momento da negação, não efetivando o momento da superação (Aufhebung) positiva.

Ter em vista tal definição de Sócrates é também estar a um passo de perceber que a constatação de que mesmo o primeiro a retratar sua personalidade, ou seja, Platão, tenha também sido, por assim dizer, "infectado" pela ironia, na medida em que foi atingido por ela, e ela passou a constituir nele um princípio negativo do pensamento ${ }^{4}$ que se encarnava através de seu Sócrates; o qual, de acordo com Kierkegaard, não estava mais próximo de captar a verdade socrática do que Aristófanes, em As Nuvens. Desse modo, se for o caso que Platão tenha adotado em sua obra um ponto de vista irônico tal qual o seu mestre, esse fato deve poder ser constatado não só através dos diálogos, nos quais a ironia se manifestaria na figura de Sócrates, mas de tal maneira que através dela se instaura uma dialética em que a ironia ultrapassa sua própria figura, e se mostraria como um “terceiro" implícito mas não excluído em termos de conteúdo; mas deve também ser constatado na figura histórica de Platão, que somente aí se arredondaria e constituiria um desenho bem delineado da sua ironia, com a qual poder-se-ia contrastar a de Sócrates. ${ }^{5}$ Se este pode ser tomado em certo sentido como o pai da filosofia, Platão não foi senão o mentor, o tutor que acompanha e direciona

3 Ironicamente, Kierkegaard afirma algo dessa magnitude numa mera nota de rodapé: "Utilizo em toda esta exposição a expressão: a ironia e o irônico, mas poderia da mesma forma dizer: o romantismo e o romântico. Ambas as expressões designam essencialmente $o$ mesmo, sendo que uma recorda mais o nome com que este partido batizou-se a si mesmo, e a outra o nome com que Hegel o batizou." (KIERKEGAARD, 2005, p. 282, nota n ${ }^{\circ}$ ).

4 “O perguntar socrático possui analogia, ainda que distante, mas indubitável, com o negativo em Hegel, só que o negativo segundo Hegel é um momento necessário no próprio pensamento, é uma determinação ad intra, e em Platão o negativo se torna visível e é colocado fora do objeto no sujeito interrogante" (KIERKEGAARD, 2005, p. 41)

5 Seria de imensurável proveito se alguém se dispusesse a elaborar um "Conceito de Ironia Constantemente Referido a Arístocles" - dado que o apelido Platão pode ser tido ele próprio um pseudônimo.

REVISTA DE ESTÉTICA E SEMIOTICA, BRASÍLIA, V. 1, N. 2 P. 50-62, JUL./DEZ. 2011 
ARTHUR BARTHOLO

seu crescimento, por outro lado tudo aparece mais desenvolvido em sua obra, principalmente naquilo que se poderia chamar a ironia absoluta do filósofo enquanto tal, como alguém que se mantém numa relação de $\varphi$ i ía com o saber, mas sem nunca explicitar que precisamente isso possibilita a ele arrogar a si mesmo o poder supremo na República.

A primeira distinção que é habitual à historiografia é a de Platão com o platonismo: este último seria um mero intermédio entre a filosofia Platônica e o cristianismo (se adotarmos aquela visão de Nietzsche na qual o cristianismo é um platonismo para o povo). Costuma-se então efetivarse aí uma disjunção: o platonismo realiza uma série de desenvolvimentos da idéia platônica que por certo divergiriam da concepção do seu idealizador. Ora, se essa visão segue-se de uma leitura escolar ou acadêmica da obra de Platão (a qual desde já não deve ser vista como um todo, visto que seus escritos esotéricos se perderam), pode-se inferir que a doutrina da filosofia platônica foi transmitida nesse âmbito de um modo no qual ela permanece como doutrina, como conhecimento objetivo, e aqui fundamentalmente devemos reconhecer o ponto onde a ironia se perde; daí se segue que esta não deve ser procurada no seus discípulos, mas somente nele próprio. $\mathrm{O}$ fato de aparentemente alguns dos diálogos platônicos terminarem em aporia e outros em discurso doutrinário não diz muita coisa, já que a própria parte doutrinária foi, reconhecidamente, por ele próprio constantemente criticada e reformulada ao longo da sua obra. Mas esse ímpeto de reformulação, de ter que recomeçar desde o princípio a cada diálogo e em cada um deles a elaboração da mesma ideia se desenvolver de maneira distinta, e a contínua hesitação ou mesmo insegurança em relação à consistência da própria teoria, a qual ele, contudo, não abandona em última instância, deixa entrever um não só uma certa distância com relação à própria teoria distância esta que é epistemologicamente necessária, pois em Platão ela de modo algum é fixa, mas circula ao redor da ideia adquirindo assim a liberdade de se assentar momentaneamente em vários pontos de vista distintos, uns mais próximos, outros mais distantes, com relação à Ideia central. Mas para que este distanciamento seja ele mesmo viável, a Ideia deve ser posta sob o registro do negativo. Aqui enfim aparece a ironia, nos moldes que Hegel determinou, quando afirma que Platão "penetrava adentro no tema com a Ideia especulativa, mas apenas começava entretanto; e ele ainda não açambarcava o todo da sua realidade na Ideia" (HEGEL, 1995) ${ }^{6}$. Mas essa ironia é aqui justamente o antípoda da ironia socrática, dado que a ideia em Sócrates nunca chegava a ser desenvolvida; tal como nos descreve Kierkegaard, ao estabelecer que o positivo se emerge no pensamento platônico na dupla determinação da especulação reflexiva e do mítico, os quais, segundo também ele próprio, “não pertencem” em nenhuma instância "a Sócrates" (KIERKEGAARD, 2005, p. 91). O seu discípulo, por sua vez, dava portanto um passo adiante, sem

6 Hegel, Lições sobre História da Filosofia, seção I, cap. 3. 
ARTHUR BARTHOLO

que no entanto assumisse para si essa positividade em sua totalidade. Ora, aqui parece que estamos diante de uma contradição, pois parece impossível, se de algum modo se assume que a ironia socrática foi imbuída em seu discípulo de modo absoluto, que haja em Platão alguma positividade; e, de outro lado, se Sócrates foi um sedutor no sentido mais estritamente espiritual, a positividade se faz presente na completude do espírito daqueles que contemplam e se fascinam pelo grande nada em que ele se situa, mas que é justamente o que dá a ele esse poder. De fato, parece que a direção em que se dá o movimento platônico é exatamente oposta à do socrático, mas que o caminho parece ainda ser o mesmo.

Se Sócrates tinha maiêutica como um método, a ironia se conforma nele como um ponto de vista (KIERKEGAARD, 2005, p. 151), o que parece não poder ser imputado a Platão. Mas se Platão foi de algum modo o porta-voz dessa ironia para a posteridade, na medida em que ele é para nós a principal mediação para a compreensão da ironia socrática, também é inconcebível que ele não a tenha entendido; e se a ironia introjetada no discurso se desenvolve junto com ele como um comensal, poder-se-ia dizer o mesmo sobre a existência: se nela alguma vez a ironia se faz presente no espírito, é inútil tentar livrar-se dela. O exemplo de Kierkegaard é aqui novamente válido: "Como Sócrates, por conseguinte, ligava de maneira tão bela os homens ao divino ao mostrar que todo conhecimento era recordação, assim também Platão se sente, numa unidade espiritual, indissoluvelmente fundido com Sócrates, de modo que todo saber é para ele um saber comum com Sócrates" (KIERKEGAARD, 2005, p. 38). Essa "indissolubilidade" não é senão um resultante da própria ironia socrática, que semeava no espírito do jovem Platão aquela ânsia típica de quem experimentou em si algo destruído na sua positividade. Mas como isso seria possível sem que a própria ironia fosse o algoz do que havia de sereno no seu espírito? O fato de Platão ter sido um poeta e tragediógrafo antes que Sócrates aparecesse não pode ter sido, sob essa ótica, senão um sintoma de que ele já era propenso a uma atitude poética. Mas qual seria o principal elemento no qual a obra platônica deixa entrever a ironia per se? Na medida em que ela mesma não pode vigorar num espírito positivo na sua totalidade, é de se questionar em que medida Platão foi capaz de reverter a validade dessa concretude em-si que a ironia socrática havia sido capaz de minar no espírito do jovem grego, principalmente após a morte de seu mestre - que, diga-se de passagem, foi quando os diálogos começaram a ser produzidos. Ora, se a condenação de Sócrates foi o elemento que engendrou não só revolta e indignação, como também perplexidade na sua atitude diante dela, em toda a sua "prole" espiritual, a sua morte constituiu para Platão em específico uma libertação, pois a partir daí qualquer resquício positivo se esvai e a Ideia pôde tornar-se de novo poeticamente livre. O que ocorreu então foi uma reversão na obra do significado concreto que Sócrates estabeleceu em vida, que na sua morte pode elevar-se para o nível da Ideia, bem entendido esta 
ARTHUR BARTHOLO

como uma ideia poética, já que Sócrates ele mesmo em termos de ideia nada deixou. Platão então assumiu a si mesmo, a partir daí, como um porta-voz de Sócrates para a eternidade, mas assim fazendo ele próprio subsumiu a figura poética de Sócrates como porta-voz da Ideia, coisa que ao Sócrates histórico seria no mínimo bastante estranha. Mas somente assim Platão poderia realizar o movimento contrário àquele que seu mestre havia realizado: se Sócrates poetizou, por assim dizer, $a$ própria existência, Platão poetizou a existência socrática no nível concreto, e poetizou a Ideia, ou seja, todo o resto, em nível abstrato; e, ao passo que a ironia de Sócrates se deu enquanto ele é um existente, em Platão ela se dá enquanto ele é autor ${ }^{7}$.

Dialeticamente, a ideia platônica corresponde, num primeiro momento, ao negativo, pois o plano supra-sensível aparece como antítese ao mundo concreto; mas essa antítese imediatamente vem a ser positiva na medida em que a Ideia adquire mais realidade que o próprio mundo sensível. Mas o fato de Platão negar a positividade desse mundo não significa de forma alguma que ele negue o mundo em absoluto; pois este subsiste de uma maneira mais etérea, ou, se quisermos, poética ${ }^{8}$. Aqui a ruptura de Platão com os eleatas se mostra como mais um sintoma, pois na medida em que os eleatas negavam qualquer realidade ao mundo sensível, Platão colocava que a realidade sensível subsiste enquanto aparência ou realidade segunda, o que a torna de certa forma muito mais esteticamente maleável do que se a essência última do Ser (que aqui só pode ser Ideia) se fizesse presente no mundo sensível. Mas assim a Ideia deixa de ser ela mesma algo antitético ao mundo, pois ela agora está indireta - ou mesmo ironicamente - subjugada ao próprio mundo. É o que Heidegger tem em mente quando enfatiza o $\alpha \gamma \alpha \theta$ ov platônico não sob o prisma moral (como comumente se traduz e se interpreta como summum bonum), mas enquanto condição de possibilidade, enquanto elemento possibilitador, tal como a luz possibilita o ver; de modo que sem ela, mesmo havendo visão e objetos a serem vistos, nada se pode ver (HEIDEGGER, 2007, p.169, 170). Isso nos diz também por quê Platão nunca foi capaz (pois talvez nunca tenha se interessado, ou tenha até mesmo evitado) de esclarecer qual era a ponte, ou o vínculo metafísico que o mundo inteligível estabelece com o sensível; ora, se isso fosse definitivamente estabelecido, toda a "elasticidade" irônica da própria Ideia estaria então perdida; pois perder-se-ia a mobilidade múltipla que nos permite flutuarmos ironicamente em liberdade em torno da Ideia.

Essa leitura de Platão só poderia ser feita sob um viés irônico, o que pode parecer um

7 Ver O Conceito de Ironia: "João viu em Cristo verdadeira e imediatamente tudo aquilo que ele representa na sua total objetividade, impondo a si mesmo o silêncio, já que seus olhos estavam imediatamente abertos para o divino em Cristo; e Platão, pelo contrário, cria o seu Sócrates por meio de uma atividade poética, já que Sócrates, precisamente em sua existência imediata, era apenas negativo" (KIERKEGAARD, 2005, p. 28) . Através dessa comparação pode-se compreender toda a produtividade poética de Platão também como uma forma de defrontar-se com esse negativo.

8 Sobre a função do "poetizar" em relação à ironia, veremos detalhadamente mais adiante. Para entendê-la aqui, basta dizer que "a ironia liberta ao mesmo tempo a poesia e o poeta"; (KIERKEGAARD, 2005, p. 275).

REVISTA DE ESTÉTICA E SEMIOTICA, BRASÍLIA, V. 1, N. 2 P. 50-62, JUL./DEZ. 2011 
ARTHUR BARTHOLO

anacronismo, mas aqui deve-se ter em mente que um ponto de vista irônico pode ser deduzido da obra platônica como um todo na medida em que ela mesma nos deixa entrever essa possibilidade. De fato, a figura de Platão é demasiado suspeita: ele não aparece em nenhum de seus diálogos (só é mencionado em dois), se utiliza de personagens, que podem funcionar exatamente da mesma maneira que pseudônimos e que têm em si mesmo uma consistência pouco delineada (inclusive o próprio Sócrates platônico), ou seja, pouca ou nenhuma positividade dialética ${ }^{9}$, e por fim se esconde ele próprio enquanto figura por trás de um pseudônimo "absoluto". Inversamente, qualquer leitura irônica de Platão só é possível na medida em que ele próprio for concebido enquanto um autor irônico, ironia esta distinta da de Sócrates, no qual ela contra tudo se volta e tudo destrói, ao passo que aqui ela se encontra subordinada à Ideia. Mas essa Ideia é ela própria uma criação, na medida em que nasce de uma negação; carrega, pois, desde a sua gênese a insígnia do poético. E essa arte de sublimar a si mesmo nesta negatividade abstrata e etérea, que faz com que aquele que procure até a última instância se depare por fim com um nada que não é senão um espelho de si próprio, enfim, essa arte de poetizar-se a si mesmo, ele não deve a ninguém senão a seu mestre.

Desse modo, a ironia se revela em Platão naquilo que se refere à reversibilidade da Ideia: nesse sentido ela só constitui o campo ontológico supremo pois esse real, justamente por ser reversível ironicamente enquanto ideia, não é senão de natureza poética. O que Platão tanto parece combater é aquilo que há de mais intrínseco a ele próprio, e ele não estava menos consciente disso; sua defrontação contra o poético só reafirma o caráter poético do seu próprio feito. Como exemplo pode-se pensar no início do livro $\mathrm{X}$ da República ${ }^{10}$, e mais adiante, a metáfora do espelho ${ }^{11}$, a qual nos sugere que o mundo não é constituído pelo mundo das ideias, mas este é constituído a partir daquele. Aí transparece um sintoma que nos aponta indiretamente para a ironia: o fato de a mimese enquanto figura de linguagem ser banida antes de mais nada nos revela por quê o caráter poético de toda a construção da cidade perfeita se anula a si mesmo, enquanto poético: se todo o poético for ele mesmo uma mimese do mundo sensível haverão nele resíduos de imperfeição, e ao mesmo tempo se tem que na cidade ideal (no sentido de que sua gênese se dá na Ideia), para que ela seja passível

9 Esses "pseudônimos", por assim dizer, são por vezes elevados à segunda potência, como no caso de Diotima, que é a porta voz do mítico no Banquete; esses artifícios têm a intenção de distanciar a fala e dar a ela menos validade positiva ao interlocutor, mas fazendo isso, a importância da própria fala é reiterada, juntamente com sua elasticidade hermenêutica, pois o falante se esconde enquanto tal por trás dela.

10 "Sócrates: - A verdade é que entre muitas razões que tenho para pensar que estivemos criando uma cidade mais perfeita do que tudo, não é das menores a nossa doutrina sobre a poesia.

Glauco: - Que doutrina?

Sócrates: - A de não aceitar a parte da poesia de caráter mimético. A necessidade de a recusar em absoluto é agora, segundo me parece, ainda mais claramente evidente, desde que definimos em separado cada uma das partes da alma", (PLATÃO, 2004, 595a-c, p. 293).

11 “(...) se quiseres pegar um espelho e andar com ele por todo lado. Em breve criarás o sol e os astros do céu, em breve a terra, em breve a ti mesmo e aos demais seres animados, os utensílios, as plantas e tudo quando há pouco referiu.

- Sim, mas são objetos aparentes, desprovidos de existência real”, (PLATÃO, 2004, 595a-c, p. 294).

REVISTA DE ESTÉTICA E SEMIOTICA, BRASÍLIA, V. 1, N. 2 P. 50-62, JUL./DEZ. 2011 
ARTHUR BARTHOLO

de uma concepção absoluta, o poético deve ser eliminado, pois ela própria, sendo de natureza poética, não poderia subsistir ao lado do poético como ente perfeito no mesmo patamar ontológico. A mimese, por sua vez, não pode coexistir com a ironia, e se o poético da mimese é o primeiro a ser banido no desenrolar da República, isso nos revela nada mais que o movimento próprio da ironia em que se encerra este diálogo: do poético absoluto anulando-se gradualmente a si mesmo. A ironia se revela aqui portanto num paradoxo, e a leitura construtiva (positiva) do diálogo se revela inconsistente: a aporia deste só pode surgir diante de nós se a ironia se mostrar como uma resolução final no diálogo em si, como um ponto de vista geral para nós.

O posterior banimento dos poetas em geral na República pode ser visto, ainda, como um ataque em si e por si ao mimético, e essa associação dos poetas com a imitação é justamente o que abre o caminho para a possibilidade da criação poética na filosofia platônica, o que, para que esta se encerre num momento, deve ter uma pretensão de absoluto, o qual, por assumir uma determinação poética ou, se quisermos, estética, nos permite ver nele não só o mundo, mas a nós mesmos no mundo. Daí se segue que o poético subsiste na eternidade através desse absoluto, mas podendo ser conquistado somente às custas do escamoteamento do real, o que se sucede, entretanto, num momento anterior àquele em que o paradoxo, ou a ironia, se efetiva em absoluto. $\mathrm{O}$ perigo que o poeta oferece enquanto autor é somente o de desvelar o ideal que se pretende passar como real e ideal ao mesmo tempo (ou seja, absoluto) e o revela como um mero negativo; a diferença aqui é que o poeta imitador reconcilia o real e o ideal, pois o mimético propõe um equilíbrio resolvido entre as partes, uma adequação (adequatio) entre aparência e essência (tal e qual no espírito metafísico: res ad intellecto). Somente ao poeta verdadeiro, ao contrário, é dado atingir a "dialética da idéia" (KIERKEGAARD, 2005, p.135), quer dizer, a dupla imbricação do ideal no real e vice- versa, e para ele clara essa separação dialética é patente; no entanto, a sombra que permanece à espreita a todo momento é a da própria ironia, que mantém sem que se perceba tudo sob o seu controle.

Tal conexão entre a ironia entre Platão e Sócrates em sua disparidade se mostra na sua importância principal em revelar o caráter poético da ironia enquanto figura do pensamento, naquilo que em Schlegel vem a se tornar, como definição da própria ironia, "um sentido artístico da vida" (Lebenskunstsinn). Se por um lado a ironia socrática se dá como uma "liberdade, infinitamente transbordante, da subjetividade", em que a abstração do pensamento se torna não somente "uma determinação metafísica quanto estética e moral" (KIERKEGAARD, 2005, p. 164), em Platão ela nos aparece mais próxima portanto daquilo que Kierkegaard chama de ironia dominada, quer dizer, uma ironia a serviço da ideia, que mesmo que não se mostre aqui então como negatividade absoluta, tampouco perde essas dimensões éticas, estéticas e metafísicas. Na poesia, ela aparece como um elemento aglutinador de diversidades e sentidos, sempre que a poesia se encontra, por assim dizer, 
ARTHUR BARTHOLO

em consonância com o seu sentido geral em termos de produção artística. Solger havia definido a ironia como "a condição de toda e qualquer produção artística" (KIERKEGAARD, 2005, p. 275), mas, bem entendido, tal ironia não é nesse sentido a ironia socrática, em que a subjetividade se deixa seduzir e se perde na liberdade do negativo. Com efeito, Kierkegaard mostra que "a ironia liberta ao mesmo tempo a poesia e o poeta. Mas para que isso possa acontecer é preciso que o próprio poeta domine a ironia" (KIERKEGAARD, 2005, p. 275), no sentido de que assim o próprio poeta se liberta para flutuar poeticamente acima da poesia, mas agora em sentido positivo. A ironia só se torna então uma disposição válida como o começo de "toda vida que se chamará digna de um homem" (KIERKEGAARD, 2005, p. 19) ${ }^{12}$ na medida em que só se faz justiça a ela superando-a ${ }^{13}$.

A necessidade de elaborar a ironia enquanto figura de linguagem se torna relevante na medida em que se a pensa num contexto de análise sígnica que devém da própria ironia enquanto disposição determinante do pensamento. Nesse sentido, ela constitui antes de tudo uma ultrapassagem da imediatidade do sentido original que a própria linguagem enquanto tal propicia nas suas figuras. Se qualquer obra ou construção linguística é vista sob uma perspectiva unidirecional, tende por sua vez a ser reduzida àquilo que o ponto de vista traz do seu direcionamento externo, quer dizer, de fora; e se, por outro lado, ela é a manifestação ou encarnação (Erscheinung) de um conceito, na medida em que este é visto como um artifício, a própria obra perde em grandeza. Por isso jamais nos é dado reduzir qualquer obra em termos absolutos a qualquer figura de construção sobre a qual ela se erija, muito embora nos seja muito bem cabido propor algumas leituras sem que estas, no entanto, tenham aquela pretensão totalitária. Se a ironia de fato trabalha com o mal-entendido (KIERKEGAARD, 2005, introdução, p. 11), a linguagem enquanto tal é imediatamente ultrapassada na sua pretensão instrumental de comunicação unívoca na medida em que a ironia é concebida, pois todo esse princípio passa a funcionar de pernas para o ar. O que acontece então é que tal concepção de linguagem se torna, por assim dizer, ridicularizada pela ironia, pois aquela se funda num terreno onde a referência é ao menos possível enquanto elemento de constituição do mundo, e na medida em que ela aparece todo o discurso parece ganhar em leveza, adquirindo com isso a capacidade de flutuar num plano acima de si próprio. Mas com isso o discurso não perde em grandeza, mas não ganha tampouco: ele parece em verdade adquirir uma segunda potência, pois passa a ser não só si mesmo e ao mesmo tempo o avesso de si mesmo mas também a ponte entre os dois, a qual é mais essencial que a significação propriamente dita. Ou, em outros termos, acontece uma duplicação no nível do significado, na qual o paradoxo se mostra como uma possibilidade concreta não mais no nível lógico, mas no estético.

Com isso se nos afigura a primeira diferença da ironia em relação a outras figuras de

12 Esta é uma das teses que o livro $O$ Conceito de Ironia intenta defender.

13 “À ironia só se pode fazer justiça superando-a" (KIERKEGAARD, 2005, p. 213).

REVISTA DE ESTÉTICA E SEMIOTICA, BRASÍLIA, V. 1, N. 2 P. 50-62, JUL./DEZ. 2011 
ARTHUR BARTHOLO

linguagem tais como o oximoro, metáfora, metonímia, etc.: no seu manifestar-se a ironia tem a capacidade de se mostrar como a chave para si mesma de fora para dentro, ao passo que assim ela aparece também como uma condição sine qua non para a manifestação de todas as outras. De fato, o signo discursivo não perde sua potencialidade sígnica no aparecer da artificialidade no artifício ${ }^{14}$ quando este é a ironia, justamente devido à sua capacidade de reversibilidade e de duplicação; e, desse modo, se é possível enxergar a obra de arte a partir de um elemento constitutivo em que ela se funda $^{15}$ - como as figuras de linguagem supracitadas - essa possibilidade requer antes de tudo uma disposição espiritual por parte do receptor, de tal maneira que ele seja de início capaz de perceber o terreno linguístico no qual ele se move. Mas para que o espírito seja introjetado na obra é preciso não só de uma dose relativamente grande de afastamento desta, para que se encontre suficientemente longe para ver onde se pisa e se saiba (até certo ponto, bem entendido) diferenciarse a si mesmo da própria obra, como também uma dose suficiente de aproximação, de tal maneira que se possa ter em vista as determinações particulares do próprio texto, sem que se perca no geral. Nesse plano é portanto improvável que qualquer figura de linguagem, ou qualquer artifício inerente ao próprio texto, tenha a possibilidade de ser visto como tal, pois este movimento acontece ainda num plano onde só é permitido ao leitor um ponto de vista unívoco, num plano onde há contato mas não há leitura propriamente dita. Aqui a duplicação irônica tem então o seu papel: a partir desse plano específico, ela efetua a sua operação de reversibilidade e o duplica no seu inverso, gerando assim um outro plano ao qual se tem livre acesso, num processo ininterrupto que leva ao infinito, pois a reduplicação do duplicado gera uma terceira instância dialética que de maneira alguma pode ser confundida com a primeira. O único problema com a ironia é que não se sabe quando ela acaba, mas isso ocorre de fato principalmente na medida em que se a limita enquanto figura objetiva da linguagem. $O$ que de fato não tem tanta relevância se se pensa que o seu conteúdo não é imediatamente determinado pelo "chistoso" $" 16$ vulgar, em que qualquer resquício de seriedade é por assim dizer volatilizado. Nela subsiste sempre a possibilidade de se dizer em tom de gracejo algo sério, bem como o contrário: "tudo nela deve ser gracejo e tudo deve ser sério: tudo sinceramente aberto e profundamente dissimulado" ${ }^{\prime 17}$.

A ironia é nesse sentido a porta que dá entrada à manifestação de qualquer alegoria ou figura

14 Como acontece com todas as outras; não que a metáfora ou a alegoria deixem de sê-lo ao passo que deles se toma consciência, mas eles tampouco saem intactos após isso: eles perdem, por assim dizer, algo na capacidade de impacto imediato, pois nesse caso a consciência é aqui reflexão, portanto, dúvida. Na ironia ocorre justamente o contrário: a sua força consiste na consciência e ela própria se alimenta da reflexão e da dúvida; ela só pode, na verdade, figurar dentro do espectro dessa consciência, pois ela própria jamais aparece enquanto tal quando vigora aquilo que Schiller chama de ingênuo (Ver SCHILLER, 2000, Poesia Ingênua e Sentimental).

15 Como pretende Kothe, A Alegoria, p. 66.

16 Como comumente se traduz, de maneira um tanto equívoca, o witz dos românticos, que talvez esteja mais próximo de "espirituosidade".

17 Schlegel, Dialeto dos Fragmentos, af. 108, p. 37.

REVISTA DE ESTÉTICA E SEMIOTICA, BRASÍLIA, V. 1, N. 2 P. 50-62, JUL./DEZ. 2011 
ARTHUR BARTHOLO

como tal, pois ela, além de posicionar o leitor numa ótica perspectivista por definição, na qual a leitura não é mais passível de ser totalitária, embora lhe seja mantida a possibilidade de ser totalizante (no sentido de sintética), ela não anula as outras figuras ou aparições poéticas no texto, mas, ao contrário, as sustenta enquanto possibilidade no plano poético. E, embora o mimético aristotélico seja um antípoda do irônico, o próprio Aristóteles por seu turno havia percebido, na sua análise da tragédia na Poética, um movimento que deixa entrever o que modernamente se chama de ironia. É interessante ver até onde a comparação entre a ironia moderna e o que se chama de "peripécia” (peripeteia) pode ser levada a cabo sem maiores distorções, pois é certo que, embora o que é chamado na Poética de peripécia seja antes um "elemento de ação complexa" do que uma figura de linguagem - sendo que este aspecto linguístico objetivo da ironia não possui na antiguidade uma proximidade conceitual ${ }^{18}$ com o sentido estético ou subjetivo que se nos mostra na modernidade, este último se deixa no entanto entrever na Poética:

A peripécia é a mudança da ação no sentido contrário ao que foi indicado e sempre, como dissemos, em conformidade com o verossímil e o necessário. Assim, no Édipo, o mensageiro que chega julga que vai dar gosto a Édipo e libertá-lo de sua inquietação relativamente a sua mãe, mas, quando se dá a conhecer, provoca o efeito contrário(...) O reconhecimento, como o nome indica, faz passar da ignorância ao conhecimento, mudando a amizade em ódio ou inversamente nas pessoas votadas à felicidade ou ao infortúnio. $\mathrm{O}$ mais belo dos reconhecimentos é o que sobrevêm de uma peripécia, como acontece no Édipo ${ }^{19}$.

Aqui, a definição mesma de peripécia é derivada da noção pura de mimese, mas a sua associação com a ideia de reconhecimento permite que esse movimento seja visto como um índice do mal-entendido típico da ironia que se faz presente; no caso do Édipo, no entanto, ela não se situa nem nos personagens em si nem na fala deles, mas na própria reviravolta a que levam os acontecimentos, ou seja, na própria peripécia. O desacordo ou a diferença não é visível de nenhum dos lados por si só, mas esse nada, esse abismo inesperado e abrupto, se faz ver justamente na contraposição, no reconhecimento. A associação deste com a peripécia poderia caracterizar o movimento da ironia aparecendo na sua negatividade, muito embora o negativo aí não seja senão o trágico mesmo. Esse movimento se mostra problemático a partir do momento em que essa negatividade venha a se mostrar como absoluta: aparece então um problema dialético, pois aí o negativo puro (que não é claramente o nada da ironia, que é antes o "nada do conteúdo determinado do mundo estabelecido" ${ }^{20}$ ) só poderia ser concebido por meio de uma mediação alheia a si mesmo.

18 Tal como nos descreve Norman Knox, Ironia.

19 Poética, capítulo XI, p. 47.

20 O Conceito de Ironia, p. 139.

REVISTA DE ESTÉTICA E SEMIOTICA, BRASÍLIA, V. 1, N. 2 P. 50-62, JUL./DEZ. 2011 


\section{ARTHUR BARTHOLO}

Desse modo, a objetividade concreta da ironia não pode mais se sustentar, e ela assim suspende a si mesma de seu estatuto de tropos linguístico, sem que contudo deixe de manifestar-se aí.

Portanto, justamente por se sustentar antes por uma atitude do que por uma necessidade meramente retórica ou linguística de expressão, a ironia pôde ultrapassar o imediato do discurso, se tornar algo mais do que ele próprio; figuras como metáfora ou zeugma têm nele o seu papel ao afetá-lo somente em termos de forma e conteúdo, não mudando-o em nada no que diz respeito à necessidade mesma de expressão; mas é exatamente contra isso que a ironia se volta, pois ela mostra que não há nada que subsista por trás daquilo mesmo que é expresso, ou melhor, ela própria se encarrega de esvaziar aquilo que há de positivo nele. Assume, portanto, uma postura negativa com relação à noção de Verdade, de tal modo que o discurso inteiro sucumbe à essa insubmissão. Assim, toda a dialética da referência e dos significados que a noção de metáfora nos traz, como Kothe nos mostra na sua análise da metáfora comparativa, só se torna possível pois esse distanciamento e a negativização do discurso que é característico da postura irônica é colocado pressupostamente: “Caso não se fizesse distinção entre o sentido literal e o metafórico, uma assertiva como 'Aquiles é um leão' só poderia ser verdadeira se houvesse um leão chamado Aquiles. A distinção não serve, contudo, para caracterizar a metáfora como linguagem fantasiosa, enfeitada; longe, portanto, da verdade" (KOTHE, 1986, p. 10). A perda da identidade consigo mesmo dos dois termos envolvidos característica à metáfora só se torna possível pois a própria realidade já não é mais idêntica consigo mesma, quer dizer, ela foi absorvida dialeticamente pelo vórtice do poético.

Nesse sentido, torna-se mais claro o que Schlegel queria dizer sobre a ironia como um sentido artístico da vida, pois ela constitui uma determinação estética do pensamento (Kunstphilosophie) que, aliada ao espírito científico (Naturphilosophie), atinge sua plenitude no "sentimento do conflito insolúvel entre incondicionado e condicionado, da impossibilidade e necessidade de uma comunicação total'(SCHLEGEL, 1997, p. 37). Desse modo, ela se caracteriza no seu fundamento como a liberdade do pensamento diante de si mesmo e que "vai além de si mesmo" (SCHLEGEL, 1997, p. 37), configurando assim na sua totalidade uma "autoparódia" que não consiste senão na infinitude do pensar a si próprio enquanto subjetividade ( sub-jectum). Desse modo, pensada num contexto semiológico, a ironia se estabelece como a instância em que se ultrapassa a unilateralidade das possibilidades de leitura objetivas: o simbólico parece querer sempre mostrar enquanto esconde, enquanto a ironia parece sempre querer esconder enquanto mostra. Na medida em que através dela se instaura o paradoxo e a dissonância entre o objetivo e o subjetivo, tal cisão é, entretanto, ao mesmo tempo sublevada pela própria ironia a ser ultrapassada na medida em que o fenômeno, que no caso da semiologia é o próprio signo, aparece agora em sua múltiplas determinações nesse jogo em que o sério é alternadamente tomado como gracejo, e vice 
ARTHUR BARTHOLO

versa.

\section{REFERÊNCIA BIBLIOGRÁFICAS}

ARISTÓTELES. Poética. São Paulo, Martin Claret, 2006.

HEIDEGGER, Martin. Nietzsche; Rio de Janeiro, Editora Forense Universitária, 2007, $1^{\text {a }}$ edição.

KIERKEGAARD, Sören. O Conceito de Ironia Constantemente Referido a Sócrates; Bragança Paulista, Editora Universitária São Francisco, 2005, $2^{a}$ edição.

KOTHE, Flávio. A Alegoria. São Paulo, Ática, 1986.

PLATÃO. Fedro. São Paulo, Martin Claret, 2004.

. República. São Paulo,Martin Claret, 2004.

SCHILLER. Poesía Ingenua y Sentimental. Madrid, Edições el Aleph, 2000.

SCHLEGEL, Friedrich. O Dialeto dos Fragmentos. São Paulo, Iluminuras, 1997.

\section{Extraídos da Internet}

HEGEL, Georg W. F. Lectures on the History of Philosophy. University of Nebraska Press, Bison book editions, 1995; seção I, cap. 3. op. cit.: http://www.marxists.org/reference/ archive/hegel/works/hp/hpsocrates.htm, acessado em 04/2010.

KNOX, Norman D. "Irony", in Dictionary of the History of Ideas: Studies of Selected Pivotal Ideas. ed. Philip P. Wiener (New York: Charles Scribner's Sons, 1973), Vol. II, pp. 626-634. op. cit.:http://www.autodidactproject.org/bib/ironybib.html, acessado em 05/2010. 